\title{
Potential contribution of African green leafy vegetables and maize porridge composite meals to iron and zinc nutrition
}

\author{
Running head \\ GLVs composite meals contribute to iron and zinc intake
}

\section{Johanita Kruger ${ }^{a}$, Tiyapo Mongwaketse $^{b}$, MiekeFaber ${ }^{c}$, Marinka van der Hoeven $^{\mathrm{b}}$, Cornelius M Smuts ${ }^{\mathrm{b}}$}

\author{
${ }^{a}$ Department of Food Science and Institute for Food, Nutrition and Well-being, University of Pretoria, \\ Private Bag X20, Hatfield 0028, South Africa; \\ ${ }^{\mathrm{b}}$ Centre for Excellence in Nutrition, North-West University, Potchefstroom; South Africa \\ ${ }^{c}$ Non-Communicable Diseases Research Unit, South African Medical Research Council, Cape Town, \\ South Africa
}

\section{Highlights}

- This study investigated the mineral nutritional value of green leafy vegetable (GLV) dishes and composite and maize porridge meals.

- GLV dishes contained average amounts of zinc, but were high in both iron and antinutrients.

- Compositing the GLV dishes with fortified maize porridge decreased the iron and zinc contents.

- The low antinutrient content of the maize porridge, led to increased amounts of bioaccessible iron and zinc in the meals.

\footnotetext{
Abstract

Objectives: This study aimed to determine the mineral nutritive value of different traditional African green leafy vegetable (GLV) dishes and their composite meals with fortified and unfortified maize porridge.

Methods: The mineral ( $\mathrm{Fe}, \mathrm{Zn}$ and $\mathrm{Ca}$ ) and anti-nutrient (phytate, total phenolics and tannins) contents and the in vitro bioaccessibility of iron and zinc were analysed. The iron and zinc contents and bioaccessibilities were used to calculate contribution these dishes and meals could make towards the recommended daily requirements and absolute requirements of vulnerable populations.
} 
Results: It was found that the GLV dishes contained average amounts of zinc (2.8-3.2 mg/100 g, dry base [db]), but were high in both iron (12.5-23.4 mg/100 g, db) and anti-nutrients (phytate 1420-2089 $\mathrm{mg} / 100 \mathrm{~g}$, db; condensed tannins $105-203 \mathrm{mg} / 100 \mathrm{~g}, \mathrm{db}$ ). The iron bioaccessibility and amount of bioaccessible iron ranged between $6.7-45.2 \%$ and $0.9-5.11 \mathrm{mg} / 100 \mathrm{~g}$, db, respectively. The zinc bioaccessibility and amount of bioaccessible zinc ranged between $6.4-12.7 \%$ and $0.63-1.63 \mathrm{mg} / 100$ g, db, respectively.

Conclusion: Importantly, while compositing the GLV dishes with fortified maize porridges decreases the iron and zinc contents, because of the low anti-nutrient content of the maize meal, the amount of bioaccessible iron and zinc in the meal increases.

Key words: iron; zinc; green leafy vegetable dishes; bioaccessibility; traditional meal; phytate; tannins

\section{Introduction}

Anaemia, of which the major cause is iron deficiency, affects 1.62 billion individuals globally [1]. Zinc deficiency has also been identified as a global public health problem, causing $1.4 \%$ of all deaths worldwide [2]. Large proportions of households in sub-Saharan Africa, where iron and zinc deficiencies are prevalent, depend on monotonous cereal based diets for energy as well as micronutrients [3]. These diets contain phytate and sometimes tannins, which, even further reduces the already low bioavailability of the non-haem iron and zinc in the diet [4].

Commercial food fortification is often regarded as one of the most successful and cost effective public health approaches for preventing micronutrient malnutrition [5] as it is a practical, sustainable, costeffective long-term solution [6]. In recent years, in the developing world, food fortification has become an increasingly attractive option and programmes are moving to the implementation phase very rapidly [7]. It has however, long been recognised that a combined approach should be used in the fight against malnutrition, and that dietary diversification with locally available, nutrient dense foods is very important to ensure sustainable increased nutrient intake [8].

It has been proposed that traditional, often wild growing African green leafy vegetables (GLVs), can play a major role to enhance the nutritional value of diets [3] and improve household food and nutrition security [9] in sub-Saharan Africa. Compared to traditionally cultivated GLVs (cabbage, spinach and kale), these traditional African GLVs are better adapted to harsh weather conditions, more resistant to pests and pathogens [10] and have similar or improved nutrient contents [3]. Most importantly, these wild growing vegetables are freely available to some of the poorest of households and communities.

There is however, a lack of information available on the cooking and preservation methods, as well as the nutrient composition of traditionally consumed GLV dishes [11]. Consequently, information on the bioaccessibility of nutrients from GLV's, their respective dishes and total meals, are also very limiting $[3,9]$. Importantly, for in vitro mineral bioaccessibility data to be most closely related to human bioavailability, food analysed, should be prepared as consumed [12]. In sub-Saharan Africa GLV 
relishes and dishes are often consumed with staple grain porridges [3]. As maize, consumed in the form of porridge, is the most important staple [13] of some vulnerable populations in Africa, it is a popular choice for national food fortification programs [7], as is the case in South Africa [14].

To our knowledge no research has been published on the bioaccessibility of iron and zinc from traditionally consumed African GLV dishes alone or when in maize porridge composite meals. This study aimed to determine the mineral nutritive value of different GLV dishes and their composite meals with maize porridge. It also aimed to assess the bioaccessibility of iron and zinc from GLV dishes, composed of various commonly consumed GLVs, alone and composited with maize porridge. The effect of maize meal fortification on the iron and zinc bioaccessibility from GLV-maize porridge composite meals was also investigated. Finally, the results were used to calculate the contribution these GLV dishes could make to the required iron and zinc intake (recommended dietary allowance RDA) of vulnerable populations. It was also estimated what contribution could be made to the absolute iron and zinc requirements (amount of required bioavailable iron and zinc) of vulnerable populations.

\section{MATERIALS AND METHODS}

\section{Materials preparation}

GLV dishes

The GLVs were cultivated on farmland approximately $50 \mathrm{~km}$ outside Potchefstroom (South Africa) from October, 2011 until February, 2012. Representative samples of the GLV dishes made and spread over the entire harvesting period were combined and processed as displayed in Figure 1. The dishes were frozen, freeze dried and stored airtight at $-20^{\circ} \mathrm{C}$ until analysed.

\section{Fortified and unfortified maize porridge}

The commercial special grade fortified maize meal (kindly donated by South African grain laboratories (SAGL) (July, 2014), who confirmed that it was fortified according to South African regulation(Fe3.5 $\mathrm{mg} / 100 \mathrm{~g}$; Zn1.5 mg/100 g) [14]. The commercial special grade non-fortified maize meal (kindly donated by Foodcorp in June, 2013) was taken out of a commercially milled batch before the mandatory fortification premix was added. The maize meal was stored in airtight containers at $5-9^{\circ} \mathrm{C}$ until use.

For the preparation of the stiff porridges, a paste was made from maize meal $(15 \mathrm{~g})$ and cold deionized water $(10 \mathrm{ml})$, which was added to boiling deionized water $(200 \mathrm{ml})$. This mixture was cooked for 10 minutes, where after $30 \mathrm{~g}$ of maize meal was added and cooked for a further 10 minutes. The fortified and unfortified porridge samples were frozen, freeze dried and stored airtight at $-20^{\circ} \mathrm{C}$ until analysed.

\section{GLV-maize porridge composite dish}

GLV- maize composites were prepared according to the proportions eaten by school children in an intervention study by van der Hoeven et al. [17] in which children consumed $125 \mathrm{~g}$ maize porridge 
served with $300 \mathrm{~g}$ of a GLV dish. In our study, each GLV dish was composited in a meal with both the fortified and unfortified maize porridge respectively at a ratio of 1:2.4 dry base (db).

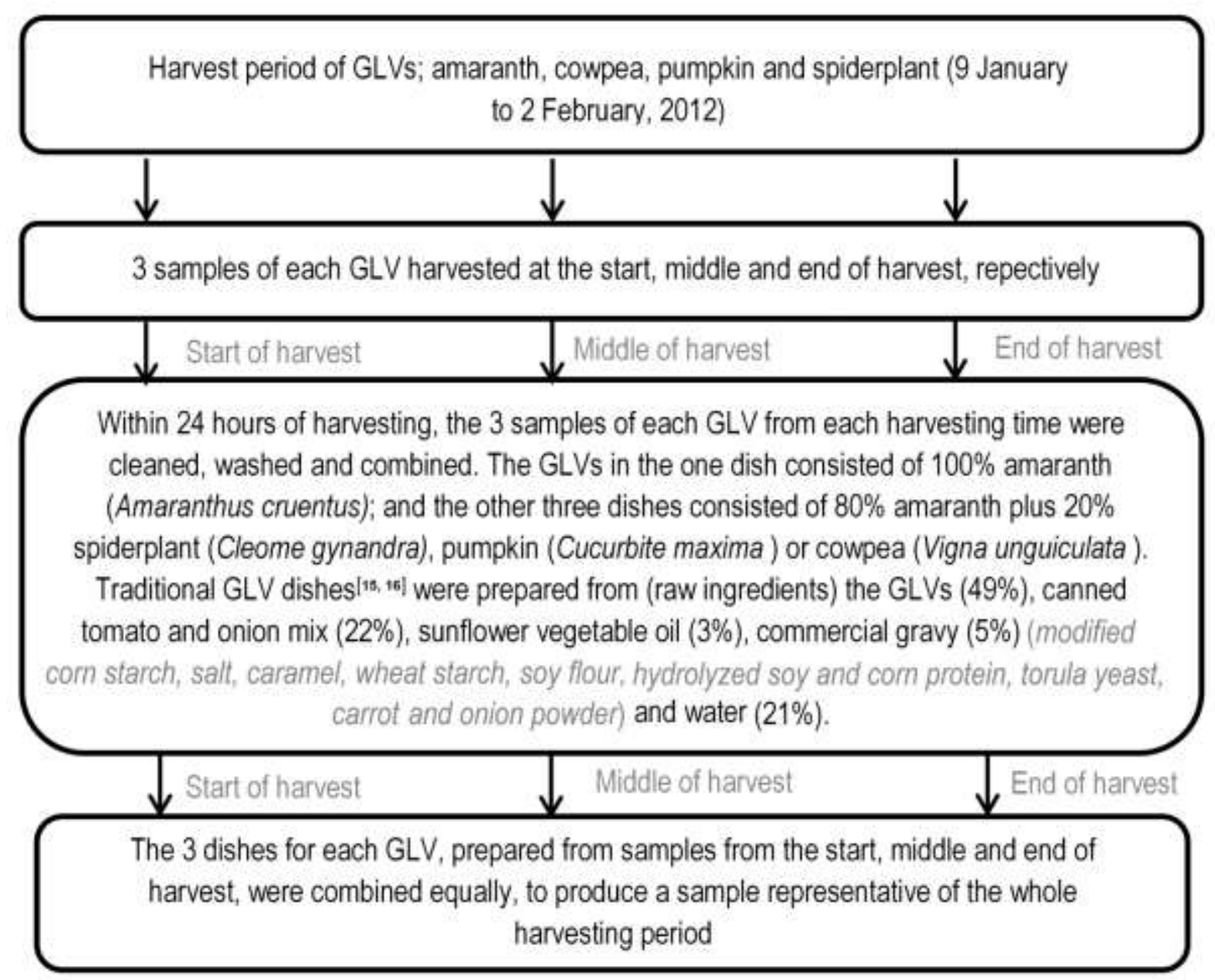

Figure 1: Harvest and preparation of traditional African green leafy vegetables (GLV) dishes

\section{Analyses}

\section{Antinutrientanalyses}

Total phenols were determined using a modified FolinCiocalteu method [18]. Tannin content was determined by the modified Vanillin $\mathrm{HCl}$ assay [19]. With both analyses sample blanks that corrected for the colour of the flour extracts were included. Phytate content was determined using the method as described by Frubecket al. [20]. The method used glass barrel Econo-columns, $0.7 \times 15 \mathrm{~cm}$ (BioRad, Johannesburg), Dowex 1; anion-exchange resin-AG 1 x 4, 4\% cross-linkage, chloride from, 100-200 mesh (Sigma, Johannesburg). 


\section{Mineral contents, bioaccessibilities analyses and mineral requirement contribution}

The total mineral contents of the maize porridge and GLV dishes were analysed by lon Coupled Plasma-Optical emission spectrophotometry (ICP-OES) after acid digestion as described by Kruger et al.[21].In vitro iron and zinc bioaccessibility was determined according to the dialysis method of Luten et al. [22] with minor modifications as described by Kruger et al.[23]. The collected digested sample (dialysate) was acidified with $0.002 \mathrm{ml} 65 \%$ nitric acid/ml dialysate, to ensure all minerals remained in solution and analysed by ICP-OES .Enzymes and reagents used were porcine pepsin and pancreatin (Sigma, Johannesburg), dialysis tubing (Spectra/Por $7(\varnothing=20.4 \mathrm{~mm})$ with a molecular mass cut-off (MMCO) of $10000 \mathrm{Da}$ ) (GIS, Johannesburg).

The contribution $100 \mathrm{~g}$ of the dishes and meals could make towards the RDA and absolute iron and zinc requirements were calculated as follows:

$\%$ contribution to RDA $=\frac{\text { Iron or zinc content }(\mathrm{mg} / 100 \mathrm{~g})}{\text { Iron or zinc requirements }(\mathrm{mg} / \text { day })} \times 100$

$\%$ contribution to absolute requirements $=\frac{\text { Iron or zinc bioaccessibility }(\mathrm{mg} / 100 \mathrm{~g})}{\text { Absolute iron or zinc requirements }(\mathrm{mg} / \text { day })} \times 100$

\section{Statistical analyses}

Statistica 12 was used to analyse for significant differences in the data using one-way analysis of variance (ANOVA) and main effects ANOVA. Tukey's Post-hoc multiple test was applied to determine significant differences between specific means at a confidence level of $95 \%(p \leq 0.05)$. All analyses were conducted on two individually prepared samples, with the replicates dependant on the precision of the method; ICP-OES -1 replicate $(n=2)$, phytate, total phenolic and tannin content - 2 replicates $(n=4)$ and mineral bioaccessibilities -2 to 3 replicates $(n>5)$. Figure 1 was constructed from Box Plots of multiple variables grouped together by dish/meal.

\section{Results and Discussion:}

\section{Mineral and anti-nutrient contents}

The amaranth-pumpkin dish and meals had the highest iron contents, while that of the amaranthspiderplant had the highest zinc contents (Table 1). The average calcium content (LS mean values) of the amaranth-cowpea dish and meals was the lowest, while there was no significant difference ( $p>0.05$ ) between the other dishes. Van Jaarsveld et al. [24] found higher mineral contents per 100g, $\mathrm{db}$ of raw amaranth (Fe 28.3mg; Zn 3.89mg; Ca $2461 \mathrm{mg}$ ), cowpea (Fe26.1 mg; Zn 2.33 mg; Ca 2161 mg), pumpkin (Fe 61.3 mg; Zn 5.00 mg; Ca 780 mg) and spiderplant (Fe16.2 mg; Zn 8.00 mg; Ca1784 mg) leaves compared to the mineral contents of the dishes in this study. This indicated that the processing (soaking) and addition of the other ingredients may have decreased the mineral contents in the dish. Despite the lower mineral contents of the dishes as compared to the raw leaves, the type of GLV still played a role in the final mineral content of the dish where iron and zinc were concerned. The cowpea and spiderplant dishes had the highest iron and zinc content respectively, 
Table 1: Mineral contents ( $\mathrm{mg} / 100 \mathrm{~g}, \mathrm{db})$ of traditional African green leafy vegetable(GLV) dishes and composite maize porridge meals

\begin{tabular}{|c|c|c|c|c|}
\hline Dish* & $\begin{array}{l}\text { Individual } \\
\text { dishes }\end{array}$ & $\begin{array}{l}\text { GLV dishes } \\
\text { composited } * * \\
\text { with thick, } \\
\text { unfortified maize } \\
\text { porridge }\end{array}$ & $\begin{array}{l}\text { GLV dishes } \\
\text { composited** with } \\
\text { thick, fortified maize } \\
\text { porridge }\end{array}$ & $\begin{array}{l}\text { Least } \\
\text { Significant } \\
\text { Mean }\end{array}$ \\
\hline \multicolumn{5}{|c|}{ Iron content $(\mathrm{mg} / \mathbf{1 0 0} \mathrm{g})$} \\
\hline $\begin{array}{l}\text { Unfortified maize } \\
\text { porridge }\end{array}$ & $1.0 \pm 0.0^{\mathrm{a}}$ & & & \\
\hline $\begin{array}{l}\text { Fortified maize } \\
\text { porridge }\end{array}$ & $4.7 \pm 0.1^{\mathrm{b}}$ & & & \\
\hline Amaranth (100\%) & $16.4 \pm 1.1^{\mathrm{efg}}$ & $12.8 \pm 0.0^{\mathrm{de}}$ & $12.5 \pm 1.0^{\mathrm{d}}$ & $13.8^{X}$ \\
\hline $\begin{array}{l}\text { Amaranth:Cowpea } \\
(80: 20)\end{array}$ & $16.9 \pm 0.3 \mathrm{f}^{\mathrm{g}}$ & $7.6 \pm 0.0^{\mathrm{c}}$ & $13.1 \pm 0.8^{\text {def }}$ & $12.5^{X}$ \\
\hline $\begin{array}{l}\text { Amaranth:pumpkin } \\
(80: 20)\end{array}$ & $23.4 \pm 0.8^{\mathrm{h}}$ & $16.6 \pm 0.7^{\mathrm{efg}}$ & $18.4 \pm 2.2^{\mathrm{gh}}$ & $19.4^{Y}$ \\
\hline $\begin{array}{l}\text { Amaranth:spider plant } \\
(80: 20)\end{array}$ & $12.5 \pm 1.2^{\mathrm{def}}$ & $11.1 \pm 0.3^{\mathrm{d}}$ & $11.3 \pm 1.0^{\mathrm{d}}$ & $11.6^{X}$ \\
\hline $\begin{array}{l}\text { Least Significant } \\
\text { Mean }\end{array}$ & $17.4^{Y}$ & $12.0^{X}$ & $14.0^{X}$ & \\
\hline \multicolumn{5}{|c|}{ Zinc content $(\mathrm{mg} / 100 \mathrm{~g})$} \\
\hline $\begin{array}{l}\text { Unfortified maize } \\
\text { porridge }\end{array}$ & $1.4 \pm 0.1^{\mathrm{a}}$ & & & \\
\hline $\begin{array}{l}\text { Fortified maize } \\
\text { porridge }\end{array}$ & $2.0 \pm 0.0^{\mathrm{b}}$ & & & \\
\hline Amaranth (100\%) & $2.81 \pm 0.01^{\mathrm{defg}}$ & $1.95 \pm 0.10^{\mathrm{b}}$ & $2.30 \pm 0.14^{\mathrm{bcd}}$ & $2.35^{X}$ \\
\hline $\begin{array}{l}\text { Amaranth:Cowpea } \\
(80: 20)\end{array}$ & $2.57 \pm 0.04^{\text {bcde }}$ & $2.20 \pm 0.01^{b c}$ & $1.80 \pm 0.15^{\mathrm{b}}$ & $2.19^{X}$ \\
\hline $\begin{array}{l}\text { Amaranth:pumpkin } \\
(80: 20)\end{array}$ & $2.72 \pm 0.27^{\text {cdef }}$ & $2.08 \pm 0.01^{\mathrm{b}}$ & $2.10 \pm 0.07^{\mathrm{bc}}$ & $2.30^{X}$ \\
\hline $\begin{array}{l}\text { Amaranth:spider plant } \\
(80: 20)\end{array}$ & $3.18 \pm 0.17^{\mathrm{fg}}$ & $3.34 \pm 0.14^{\mathrm{g}}$ & $2.90 \pm 0.16^{\mathrm{efg}}$ & $3.13^{Y}$ \\
\hline $\begin{array}{l}\text { Least Significant } \\
\text { Mean }\end{array}$ & $2.8^{Y}$ & $2.4^{X}$ & $2.3^{X}$ & \\
\hline \multicolumn{5}{|c|}{ Calcium content $(\mathrm{mg} / 100 \mathrm{~g})$} \\
\hline $\begin{array}{l}\text { Unfortified maize } \\
\text { porridge }\end{array}$ & ND & & & \\
\hline $\begin{array}{l}\text { Fortified maize } \\
\text { porridge }\end{array}$ & ND & & & \\
\hline Amaranth $(100 \%)$ & $947 \pm 111^{\mathrm{e}}$ & $668 \pm 3^{\text {bcde }}$ & $860 \pm 42^{\mathrm{de}}$ & $825^{Y}$ \\
\hline $\begin{array}{l}\text { Amaranth:Cowpea } \\
(80: 20)\end{array}$ & $726 \pm 56^{\text {cde }}$ & $211 \pm 1^{\mathrm{a}}$ & $394 \pm 9^{\mathrm{ab}}$ & $444^{X}$ \\
\hline $\begin{array}{l}\text { Amaranth:pumpkin } \\
(80: 20)\end{array}$ & $863 \pm 81^{\text {de }}$ & $500 \pm 28^{\mathrm{bc}}$ & $588 \pm 29^{\text {bcd }}$ & $651^{Y}$ \\
\hline $\begin{array}{l}\text { Amaranth:spider plant } \\
(80: 20)\end{array}$ & $591 \pm 0^{\mathrm{bcd}}$ & $629 \pm 8^{\mathrm{bcd}}$ & $512 \pm 34^{\mathrm{bc}}$ & $577^{X Y}$ \\
\hline $\begin{array}{l}\text { Least Significant } \\
\text { Mean }\end{array}$ & $781^{Y}$ & $502^{X}$ & $589^{X}$ & \\
\hline
\end{tabular}

Values expressed as average of 2 individual analyses in $\mathrm{mg} / 100 \mathrm{~g} \pm 1 \mathrm{SD},{ }^{\text {abc }}$ - Values of the same mineral with different superscripts, differ significantly $(\mathrm{p} \leq 0.05),{ }^{\mathrm{XYZ}}$ - Least Significant Mean values with different superscripts in the same row/column, differ significantly ( $\mathrm{p} \leq 0.05),{ }^{*}$ Each dish (raw ingredients) consisted of GLVs (49\%), tomatoes and onion mix (22\%), vegetable oil (3\%), a commercially available instant gravy powder $(5 \%)$ and water $(21 \%),{ }^{* *}$ Dishes were composited at a low ratio of porridge:GLV (1:2.4, db). ND - Not detected(below the detection level) 
corresponding with that of the values of the raw leaves. The mineral contents of both the unfortified and fortified maize porridge were lower than the GLV dishes and as expected, compositing the GLV dishes with the maize porridges decreased the contents of all the measured minerals in the meals.

While there were small differences between the mineral contents of the GLV-fortified - and GLVunfortified maize porridge composite meals, even in some instances lower values for the unfortified maize composite meals, these differences were not significant $(p>0.05)$. This was probably because the GLV dishes had much higher mineral contents compared to the maize porridges and the meals contained less than halve the amount of porridge compared to GLV.

The phytate contents of the maize porridges (Table 2) were 1.5 to 4 times lower than that of the GLV dishes and as expected, when the GLVs were composited with the maize porridges, the phytate contents were decreased. The composite GLV-fortified maize porridge meals had the lowest phytate contents.

Table 2:Phytate contents ( $\mathrm{mg} / 100 \mathrm{~g}, \mathrm{db})$ and calculated phytate:iron molar ratios of traditional African green leafy vegetable $(G L V)$ dishes and maize composite maize porridge meals

\begin{tabular}{|c|c|c|c|c|}
\hline Dish* & $\begin{array}{l}\text { Individual } \\
\text { dishes }\end{array}$ & $\begin{array}{l}\text { GLV dishes } \\
\text { composited }{ }^{* *} \text { with } \\
\text { thick, unfortified } \\
\text { maize porridge }\end{array}$ & $\begin{array}{l}\text { GLV dishes } \\
\text { composited** with } \\
\text { thick, fortified maize } \\
\text { porridge }\end{array}$ & $\begin{array}{l}\text { Least } \\
\text { Significant } \\
\text { Mean }\end{array}$ \\
\hline \multicolumn{5}{|l|}{$\begin{array}{l}\text { Unfortified maize } \\
\text { porridge } \\
\text { Fortified maize } \\
\text { porridge }\end{array}$} \\
\hline \multirow{4}{*}{$\begin{array}{l}\text { Amaranth }(100 \%) \\
\text { Amaranth:Cowpea } \\
(80: 20) \\
\text { Amaranth:pumpkin } \\
(80: 20) \\
\text { Amaranth:spider } \\
\text { plant }(80: 20)\end{array}$} & $2089 \pm 167^{\mathrm{e}}[11]$ & $1711 \pm 92^{\text {bcde }}[11]$ & $1842 \pm 189^{\text {cde }}[12]$ & \multirow{2}{*}{$\begin{array}{l}1877^{Z} \\
1600^{Y}\end{array}$} \\
\hline & $1822 \pm 201^{\text {de }}[9]$ & $1629 \pm 97^{\text {bcde }}[18]$ & $1348 \pm 67^{b c}[9]$ & \\
\hline & $1420 \pm 142^{\mathrm{bcd}}[5]$ & $1266 \pm 104^{b c}[6]$ & $1088 \pm 80^{b}[5]$ & $1258^{x}$ \\
\hline & $1543 \pm 95^{b c}[10]$ & $1533 \pm 113^{b c}[12]$ & $1270 \pm 90^{b}[10]$ & \\
\hline $\begin{array}{l}\text { Least Significant } \\
\text { Mean }\end{array}$ & $1715^{z}$ & $1535^{Y}$ & $1397^{X}$ & \\
\hline $\begin{array}{l}\text { Values expresse } \\
\text { phytate:iron mo } \\
(\mathrm{p} \leq 0.05) \text { based } \\
\text { superscripts in } \mathrm{tl} \\
\text { test, } * \text { Each dish } \\
\text { oil }(3 \%) \text {, a comr } \\
\text { composited at a }\end{array}$ & $\begin{array}{l}\text { verage of } 2 \text { indivi } \\
\text { tios, }{ }^{\text {acc }} \text {-Values wi } \\
\text { post-hoc Tukey } \mathrm{H} \\
\text { ne column, differ } \\
\text { ngredients) consis } \\
\text { lly available insta } \\
\text { tio of porridge: } \mathrm{G}\end{array}$ & $\begin{array}{l}\text { duplicate analyses in } \mathrm{ms} \\
\text { fferent superscripts in th } \\
\text { test, }{ }^{\mathrm{XYZ}} \text { - Least Signific } \\
\text { ficantly (p } \leq 0.05 \text { ) based } \\
\text { f GLVs }(49 \%) \text {, tomatoe } \\
\text { avy powder }(5 \%) \text { and w } \\
1: 2.4 \text {, db). }\end{array}$ & $\begin{array}{l} \pm \mathrm{SD},[] \text { - calculated } \\
\text { e column, differ significantl } \\
\text { ean values with different } \\
\text { post-hoc Tukey HSD } \\
\text { onion mix (22\%), vegetable } \\
1 \%),{ }^{* *} \text { Dishes were }\end{array}$ & \\
\hline
\end{tabular}


All of the phytate:iron molar ratios, ranging from 5 to 18 (Table 2, square brackets), were higher than the critical ratio of 1 , above which the availability of iron has been found to be seriously impaired [24]. The reduction in phytate content upon compositing with the maize porridges did not result in reduced phytate:iron ratios, because of the simultaneous reduction in iron content (Table 1). The phytate:zinc and phytate $x$ calcium:zinc ratios ranged between $43-87$ and 386-1731, well above their respective critical ratios of $10-14$ [25] and 200[26].

The maize porridges were essentially free from tannins $(39-82 \mathrm{mg} / 100 \mathrm{~g})($ Table 3$)$. There were no significant differences between the phenolic contents of the different GLV dishes and the amaranth dish contained the most tannins. The tannin contents of the GLV dishes measured relatively low (105-203 mg/100 g) compared to literature values of the main raw product amaranth; $450 \mathrm{mg} / 100 \mathrm{~g}$ (db) [27]. However, a reduction in measurable tannin content after heat treatment may be due to the reaction of phenolic hydroxyl groups with food components, such as protein and minerals, like iron, to form insoluble complexes [28]. This in effect, would not reduce the actual inhibiting power of the tannins, but just their extractability.

Table 3: Phenolic and Tannin contents (mg catechin equivalents $(C E) / 100 \mathrm{~g}, \mathrm{db})$ of traditional African green leafy vegetable (GLV) dishes

\begin{tabular}{lll}
\hline Dish* & Total phenolics & Tannins \\
\hline Unfortified maize porridge & ND & $39 \pm 18^{\mathrm{a}}$ \\
Fortified maize porridge & ND & $82 \pm 7^{\mathrm{b}}$ \\
Amaranth (100\%) & $1234 \pm 40^{\mathrm{a}}$ & $203 \pm 28^{\mathrm{d}}$ \\
Amaranth-Cowpea (80:20) & $1170 \pm 77^{\mathrm{a}}$ & $183 \pm 5^{\mathrm{cd}}$ \\
Amaranth-Pumpkin (80:20) & $1244 \pm 79^{\mathrm{a}}$ & $166 \pm 15^{\mathrm{c}}$ \\
Amaranth-Spider plant (80:20) & $1297 \pm 86^{\mathrm{a}}$ & $105 \pm 8^{\mathrm{b}}$ \\
\hline \multicolumn{2}{c}{ Values expressed as average of 2 individual analyses in mg/100 g \pm SD, ND-Not } \\
\multicolumn{2}{c}{ Detected. abc - Values with different superscripts in the same column, differ } \\
\multicolumn{2}{c}{ significantly (p $\leq 0.05)$ based on the post-hoc Tukey HSD test, *Each dish (raw } \\
\multicolumn{2}{c}{ ingredients) consisted of GLVs (49\%), tomatoes and onion mix (22\%), vegetable oil } \\
(3\%), a commercially available instant gravy powder (5\%) and water (21\%).
\end{tabular}

\section{Iron and zinc bioaccessibilities}

Both the mineral bioaccessibilities (\%) and the amount of bioaccessible mineral ( $\mathrm{mg} / 100 \mathrm{~g}$ ) values were presented in Tables 4 and 5 . The percentage mineral bioaccessibility gives a good indication of the sum of the effects of the mineral bioaccessibility inhibitors and enhancers and the total amount of the specific mineral in the dish/meal. However, when the total mineral contents of samples are substantially different, as in this study, there was the possibility that the $\%$ bioaccessibility values might be somewhat misleading. For example, the \% iron bioaccessibility of the unfortified maize porridge $(22.0 \%)$ was more than three times that of the fortified maize porridge $(6.2 \%)$ (Table 4$)$. However, there was no significant difference $(p>0.05)$ between the amount of bioaccessible iron $(0.22$ and $0.29 \mathrm{mg} / 100 \mathrm{~g}$, respectively). 
Table 4: Iron bioaccessibility (\% of total iron indish/meal) and amount of bioaccessible iron (mg/100 g dish/meal, db) of traditional African green leafy vegetable (GLV) dishes composited with fortified and unfortified maize porridges

\begin{tabular}{|c|c|c|c|c|c|c|c|c|}
\hline \multirow{3}{*}{ Dish* } & \multicolumn{6}{|c|}{ Iron bioaccessibility $(\%)$ and amount of bioaccessible iron $(\mathrm{mg} / 100 \mathrm{~g})$} & \multirow{3}{*}{$\begin{array}{l}\text { Least Significant } \\
\text { Mean for \% } \\
\text { bioaccessible } \\
\text { iron }\end{array}$} & \multirow{3}{*}{$\begin{array}{l}\text { Least Significant } \\
\text { Mean for mg/100 } g \\
\text { bioaccessible iron }\end{array}$} \\
\hline & \multicolumn{2}{|c|}{ Individual dishes } & \multicolumn{2}{|c|}{$\begin{array}{c}\text { GLV dishes composited } * * \\
\text { with thick, unfortified maize } \\
\text { porridge }\end{array}$} & \multicolumn{2}{|c|}{$\begin{array}{l}\text { GLV dishes composited } * * \\
\text { with thick, fortified maize } \\
\text { porridge }\end{array}$} & & \\
\hline & $\%$ & $\mathrm{mg} / 100 \mathrm{~g}$ & $\%$ & $\mathrm{mg} / 100 \mathrm{~g}$ & $\%$ & $\mathrm{mg} / 100 \mathrm{~g}$ & & \\
\hline Unfortified maize porridge & $22.0 \pm 6.5^{\mathrm{d}}$ & $0.22 \pm 0.65^{\mathrm{A}}$ & & & & & & \\
\hline Fortified maize porridge & $6.2 \pm 1.2^{\mathrm{a}}$ & $0.29 \pm 0.06^{\mathrm{A}}$ & & & & & & \\
\hline Amaranth $(100 \%)$ & $9.7 \pm 3.6^{\mathrm{a}}$ & $1.60 \pm 0.59^{\mathrm{BC}}$ & $16.7 \pm 4.5^{\mathrm{bc}}$ & $2.13 \pm 0.57^{\mathrm{BC}}$ & $30.1 \pm 6^{\mathrm{f}}$ & $3.76 \pm 0.74^{\mathrm{E}}$ & $19^{Y}$ & $2.5^{Y Z}$ \\
\hline Amaranth-Cowpea $(80: 20)$ & $10.1 \pm 1.4^{\mathrm{a}}$ & $1.71 \pm 0.23^{\mathrm{BC}}$ & $21.7 \pm 2.5^{\mathrm{cd}}$ & $1.65 \pm 0.19^{\mathrm{BC}}$ & $23.0 \pm 2.5^{\mathrm{de}}$ & $3.02 \pm 0.33^{\mathrm{D}}$ & $18^{Y}$ & $2.1^{X Y}$ \\
\hline Amaranth-Pumpkin (80:20) & $6.8 \pm 0.9^{\mathrm{a}}$ & $1.60 \pm 0.20^{\mathrm{BC}}$ & $6.7 \pm 1.0^{\mathrm{a}}$ & $1.12 \pm 0.16^{\mathrm{B}}$ & $12.1 \pm 2 b^{\mathrm{ab}}$ & $1.78 \pm 0.10^{\mathrm{C}}$ & $8^{X}$ & $1.6^{X}$ \\
\hline Amaranth-Spider plant $(80: 20)$ & $25.0 \pm 3.5^{\mathrm{e}}$ & $3.14 \pm 0.44^{\mathrm{D}}$ & $14.2 \pm 1.5^{\mathrm{b}}$ & $1.57 \pm 0.17^{\mathrm{BC}}$ & $45.2 \pm 1.8^{\mathrm{g}}$ & $5.11 \pm 0.20^{\mathrm{F}}$ & $23^{Y}$ & $2.7^{Z}$ \\
\hline Least Significant Mean & $11^{X}$ & $1.9^{X}$ & $15^{X}$ & $1.6^{X}$ & $25^{Y}$ & $3.3^{Y}$ & & \\
\hline
\end{tabular}


Table 5: Zinc bioaccessibility (\% of total zinc in dish/meal) and amount of bioaccessible zinc (mg/100 gdish/meal, db) of traditional African green leafy vegetable (GLV) dishes composited with fortified and unfortified maize porridges

\begin{tabular}{|c|c|c|c|c|c|c|c|c|}
\hline \multirow[b]{3}{*}{ Dish* } & \multicolumn{6}{|c|}{ Zinc bioaccessibility (\%) and amount of bioaccessible zinc (mg/100 g) } & \multirow{3}{*}{$\begin{array}{l}\text { Least Significant } \\
\text { Mean for \% } \\
\text { bioaccessible } \\
\text { zinc }\end{array}$} & \multirow{3}{*}{$\begin{array}{l}\text { Least Significant } \\
\text { Mean for mg/100 } \mathrm{g} \\
\text { bioaccessible zinc }\end{array}$} \\
\hline & \multicolumn{2}{|c|}{ Individual dishes } & \multicolumn{2}{|c|}{$\begin{array}{l}\text { GLV dishes composited } * * \\
\text { with thick, unfortified maize } \\
\text { porridge }\end{array}$} & \multicolumn{2}{|c|}{$\begin{array}{l}\text { GLV dishes composited } * * \\
\text { with thick, fortified maize } \\
\text { porridge }\end{array}$} & & \\
\hline & $\%$ & $\mathrm{mg} / 100 \mathrm{~g}$ & $\%$ & $\mathrm{mg} / 100 \mathrm{~g}$ & $\%$ & $\mathrm{mg} / 100 \mathrm{~g}$ & & \\
\hline Unfortified maize porridge & $12.2 \pm 2.7^{\mathrm{e}}$ & $0.16 \pm 0.14^{\mathrm{A}}$ & & & & & & \\
\hline Fortified maize porridge & $7.3 \pm 1.1^{\mathrm{ab}}$ & $0.15 \pm 0.05^{\mathrm{A}}$ & & & & & & \\
\hline Amaranth $(100 \%)$ & $7.0 \pm 0.4^{\mathrm{ab}}$ & $1.15 \pm 0.06^{\mathrm{C}}$ & $8.1 \pm 1.0^{\mathrm{ab}}$ & $1.04 \pm 0.13^{\mathrm{BC}}$ & $8.0 \pm 1^{\mathrm{d}}$ & $0.99 \pm 0.12^{\mathrm{BC}}$ & $8^{x}$ & $1.1^{x}$ \\
\hline Amaranth-Cowpea (80:20) & $7.3 \pm 0.4^{\mathrm{ab}}$ & $1.24 \pm 0.07^{\mathrm{CD}}$ & $8.4 \pm 0.4^{\mathrm{cd}}$ & $0.63 \pm 0.03^{\mathrm{B}}$ & $7.2 \pm 0.6^{\mathrm{ab}}$ & $0.95 \pm 0.08^{\mathrm{BC}}$ & $8^{x}$ & $0.9^{x}$ \\
\hline Amaranth-Pumpkin (80:20) & $7.0 \pm 0.4^{\mathrm{ab}}$ & $1.63 \pm 0.10^{\mathrm{D}}$ & $7.2 \pm 0.2^{\mathrm{abc}}$ & $1.19 \pm 0.03^{\mathrm{C}}$ & $6.7 \pm 0.6^{\mathrm{ab}}$ & $0.98 \pm 0.56^{\mathrm{BC}}$ & $7^{x}$ & $1.4^{\gamma}$ \\
\hline Amaranth-Spider plant $(80: 20)$ & $8.1 \pm 0.3^{\text {bcd }}$ & $1.02 \pm 0.04^{\mathrm{BC}}$ & $6.4 \pm 0.3^{\mathrm{a}}$ & $0.71 \pm 0.04^{\mathrm{B}}$ & $12.7 \pm 0.2^{\mathrm{e}}$ & $1.44 \pm 0.03^{\mathrm{CD}}$ & $8^{x}$ & $0.9^{x}$ \\
\hline Least Significant Mean & $7^{X}$ & $1.3^{Z}$ & $7^{X}$ & $0.9^{X}$ & $8^{X}$ & $1.1^{Y}$ & & \\
\hline
\end{tabular}


The iron bioaccessibility and amount of bioaccessible iron ranged between $6.7-45.2 \%$ and $0.9-5.11$ $\mathrm{mg} / 100 \mathrm{~g}$, respectively (Table 4). The low bioaccessibilities of iron in the amaranth-pumpkin dish and meals $(6.7-12.1 \%)$ were unexpected, because of the lower phytate:iron molar ratios (5-6, Table 2), compared to the other dishes and meals (9-18). The phytate and iron contents of the amaranthpumpkin dish and meals were significantly lower and higher, respectively, compared to the other dishes. The low bioaccessibility of the iron in the pumpkin may be due to contamination iron, despite careful cleaning. Pumpkin leaves grow on vines, close to the ground which increases the amount of soil and dust contamination. Van Jaarsveld et al. [24] analysed the nutrient content of African GLV's and found that the pumpkin leaves were more susceptible to mineral contamination as it required more rinsing to remove all the soil from the leaves (personal communication with $\mathrm{P}$ van Jaarsveld). Contamination iron, as was probably present in the pumpkin leaves, has been found to not be bioaccessible [29]. The amaranth-spiderplant, fortified maize porridge meal could provide the most bioaccessible iron, compared to all the other dishes and meals. While this meal had similar iron (Table 1), phytate (Table 2) and phenolic contents (Table 3) compared to the rest of the dishes and meals, the amaranth-spider plant dish had the lowest tannin content (Table 3). Importantly, it has been found that the inhibitory effect of condensed tannins on iron bioaccessibility can be much stronger than that of phytate [30].

Compositing the GLV dishes with the unfortified maize porridge did not result in any significant ( $p>0.05$ ) change in the percentage iron bioaccessibility or the amount of bioaccessible iron. However, compositing with the fortified maize porridge significantly $(p \leq 0.05)$ improved the percentage iron bioaccessibility and the amount of bioaccessible iron. This increase in iron bioaccessibility is probably a combination of two factors; firstly the fortified maize porridge contained less inhibitors of iron absorption (phytate, tannins and total phenolics) than the GLV dishes (Tables 2 and 3). Secondly, the fortified maize porridge contained almost 5 times more iron (Table 1) than the unfortified porridge.

The zinc bioaccessibility and amount of bioaccessible zinc ranged between $6.4-12.7 \%$ and $0.63-1.63$ $\mathrm{mg} / 100 \mathrm{~g}$, respectively (Table 5 ). Overall, there were no significant differences $(p>0.05)$ in zinc bioaccessibilities between the different GLV dishes or their respective maize porridge meals. The low zinc bioaccessibilities in general and the lack of increase or decrease after compositing with the maize porridges may be due to the low zinc contents, together with the high calcium and phytate contents, reiterated by the high phytate:zinc (43-87) and calcium x phytate:zinc ratios (386-1731). However, the amount of bioaccessible zinc was the highest for the amaranth-pumpkin dish and meals $(1.4 \mathrm{mg} / 100 \mathrm{~g})$ compared to the other GLV dishes $(0.9-1.1 \mathrm{mg} / 100 \mathrm{~g})$. This is in direct contrast to the trends observed for the amount of bioaccessible iron. It has been found that iron can inhibit zinc absorption [31] and this might be an additional inhibiting factor. 
A The contribution (\%) $100 \mathrm{~g}$ traditional African green leafy vegetables (GLV) dishes and meals can make to the iron requirements of children younger than 5 years of age (based on RDA - $10 \mathrm{mg}$ /day and absolute requirements $0.50 \mathrm{mg} / \mathrm{day}$ ) Mear: Box MoantSE; Whisker. Masnt2?SD

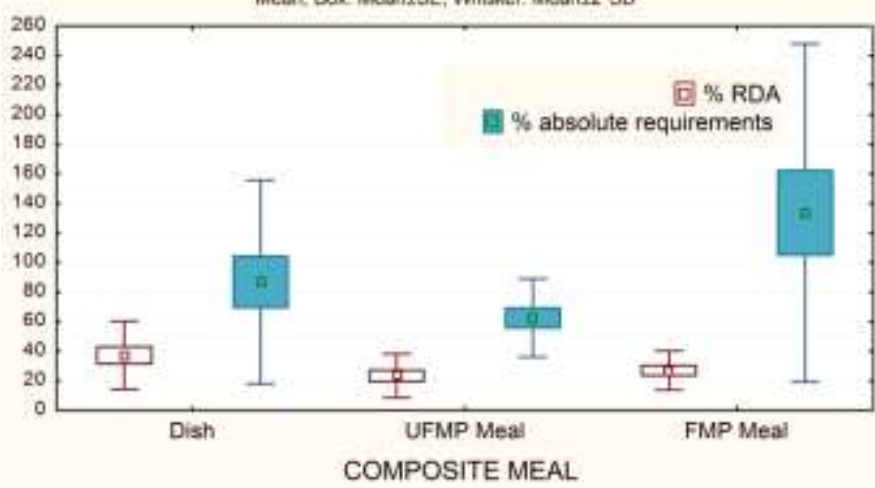

C The contribution ( $\%$ ) $100 \mathrm{~g}$ traditional African green leafy vegetables (GLV) dishes and meals can make to the zinc requirements of children younger than 5 years of age (based on RDA - $5 \mathrm{mg}$ /day and absolute requirements $1.09 \mathrm{mg} /$ day) Mean; Box: MosntSE; Whisker; Mesnt?'SD

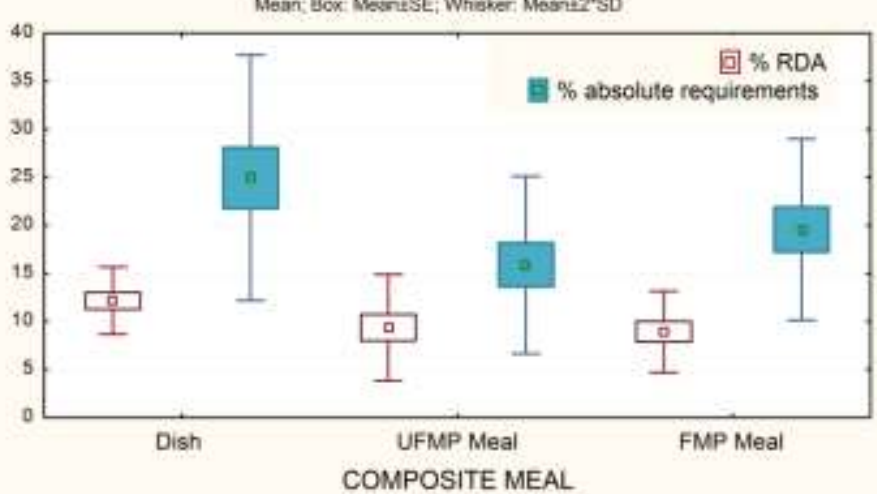

B The contribution (\%) $100 \mathrm{~g}$ traditional African green leafy vegetables (GLV) dishes and meals can make to the iron requirements ofvomen of childbearing age, pregnant and lactating (based on RDA -27 mg/day and absolute requirements $1.64 \mathrm{mg} /$ day) Mean, Boc Mean \pm SE: Whisker: Meant2-50

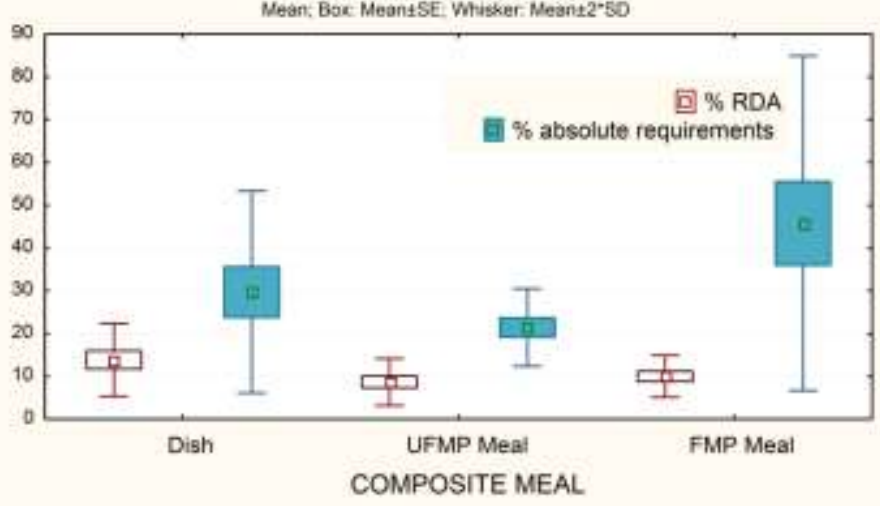

D The contribution (\%) $100 \mathrm{~g}$ traditional African green leafy vegetables (GLV) dishes and meais can make to the iron requirements ofvomen of childbearing age, pregnant and lactating (based on RDA - 12 mg/day and absolute requirements $3.36 \mathrm{mg} /$ day) Jeen Box: MeantSE; Whisker Meant2-SD



Figure 2: An estimation of the contribution traditional African green leafy vegetable (GLV) dishes and their composite maize porridge meals can make to the highestrecommended dietary allowances (RDA) and absolute requirements of iron and zinc of $(A$ and $C$ ) children younger than 5 years of age and $(B$ and $D$ ) women of child bearing age, pregnant and lactating.

UFMP - Unfortified maize porridge, FMP - Fortified maize porridge,

Highest RDA and absolute iron and zinc requirements for women and children $<5$ years of age were selected.

A: In both cases for women it was the recommendations for pregnant women; RDA - $27 \mathrm{mg} / \mathrm{day}(\mathrm{IOM}, 2001)$ and absolute requirements $1.46 \mathrm{mg} / \mathrm{day}$ (WHO, 2008).

B: In both cases for children $<5$ it was the recommendations for 37-60 month toddlers; RDA - $10 \mathrm{mg} /$ day $(\mathrm{IOM}, 2001)$ and absolute requirements $-0.50 \mathrm{mg} / \mathrm{day}(\mathrm{WHO}, 2008)$.

$\mathrm{C}$ : In both cases for women it was the recommendations for lactating women; RDA - $12 \mathrm{mg} / \mathrm{day}$ (IOM, 2001) and absolute requirements $3.36 \mathrm{mg} /$ day (FAO/WHO, 2001).

D: In both cases for children <5 it was the recommendations for 37-60 month toddlers; RDA - 5 mg/day (IOM, 2001) and absolute requirements $-1.09 \mathrm{mg} /$ day (FAO/WHO, 2001).

Each dish (raw ingredients) consisted of GLVs $(49 \%)$, tomatoes and onion mix (22\%), vegetable oil (3\%), a commercially available instant gravy powder $(5 \%)$ and water $(21 \%)$ and dishes were composited at a low ratio of porridge:GLV $(1: 2.4, \mathrm{db})$.

\section{Contributions the dishes and meals can make towards the iron and zinc intake of vulnerable populations}

The highest iron and zinc requirement within each vulnerable populations [32]; children (1-5 years of age) and women (including childbearing age, pregnant and lactating), were used to compare to the mineral nutritional values of the dishes and meals (Figure 2). This was done to ensure that the contributions displayed would be the minimum within each vulnerable population group, to in no way 
overestimate the contribution. The total mineral contents were used to estimate the average contribution that $100 \mathrm{~g}$ of the dishes and meals could make towards the iron and zinc RDA of children and women. The mineral bioaccessibilities were used to estimate the contribution that $100 \mathrm{~g}$ of these dishes can make towards the absolute requirements for iron and zinc (absolute requirements include requirements for growth, basal losses and, in females, menstrual losses). The highest iron requirements in each vulnerable group were, in both cases, for pregnant women (RDA27 mg/day [33]; absolute requirements $1.46 \mathrm{mg} /$ day [34]) and 37-60 month toddlers (RDA $10 \mathrm{mg} / \mathrm{day}$ [32]; absolute requirements $0.50 \mathrm{mg} /$ day [34]). The highest zinc requirements were in both cases for lactating women (RDA12 mg/day [33]; absolute requirements $3.36 \mathrm{mg} /$ day [35]) and 37-60 month toddlers (RDA5 mg/day [33]; absolute requirements $1.09 \mathrm{mg} /$ day [35]).

The GLV dishes, unfortified and fortified maize porridge meals could provide at least 34,21 and $24 \%$ of the iron RDA to children and 14, 9 and $10 \%$ of the iron RDA to women, respectively. The GLV dishes, unfortified and fortified maize porridge meals could provide at least 12,9 and $9 \%$ of the zinc RDA to children and 5, 4 and $4 \%$ of the zinc RDA to women, respectively. The meals and dishes could contribute much more towards the requirements for iron, compared to zinc.

When evaluating the contribution the bioaccessible minerals can make towards the absolute requirements for iron and zinc, the direction of the effect is more reliable than the magnitude [15]. The bioaccessibility data was used to calculate if compositing with maize porridges would negatively or positively affect the mineral bioaccessibility of the GLV dishes (Figures 1 and 2). Interestingly, despite the reduction in iron content, compared to the GLV dish alone, there was an increase in the contribution the fortified maize porridge meals could make towards the absolute requirements of iron for both children (93 vs. $60 \%$ ) and women ( 46 vs. $30 \%$ ). This showed that while the contribution to the RDA was decreased, compositing the GLV dishes with the fortified maize porridge increased the contribution to the absolute iron requirements. While the same trend was observed for the contribution the bioaccessible zinc could make towards the absolute requirements, it was considerably less pronounced.

\section{Conclusions}

The traditional African GLV dishes and meals are high in minerals and regular consumption could make a considerable contribution to the recommended daily allowance of iron to vulnerable populations. However, as is the problem with all plant based diets, the contribution of zinc is lower. Importantly, while compositing the GLV dishes with fortified maize porridge decreases the iron and zinc contents, due to the low anti-nutrient content of the maize meal compared to the GLV dishes, the amount ofbioaccessible iron and zinc increases.

\section{Acknowledgments}

We would like to thank Sight and Life for funding parts of the research. The authors are also grateful to Willem Jansen van Rensburg of the Argicultural Research Council, Roodeplaat, South Africa for 
providing the GLV seed and Herman Fouché and his team at Muiskraal, Rysmierbult, South Africa for the cultivation of the GLVs.

\section{References}

1. World Health Organization (WHO). Worldwide prevalence of anaemia 1993-2005: WHO Global Database on Anaemia. Geneva: WHO Press; 2008a.

2. World Health Organization (WHO). World health report 2013: Research for universal health coverage. Geneva: WHO Press; 2013.

3. Uusiku NP, Oelofse A, Duodu KG, Bester MJ, Faber M. Nutritional value of leafy vegetables of sub-Saharan Africa and their potential contribution to human health: $A$ review. J Food Comp Anal 2010;23:499-509.

4. Hunt JR. Bioavailability of iron, zinc, and other trace minerals from vegetarian diets. Am J ClinNutr 2003;78:633S-9S.

5. Miller BDD, Welch RM. Food system strategies for preventing micronutrient malnutrition. Food Policy 2013;42:115-28.

6. Zimmermann MB, Hurrell RF. Nutritional iron deficiency. Lancet, 2007;370:511-20.

7. Allen L, De Benoist B, Dary O, Hurrell R. Guidelines on food fortification with micronutrients. Geneva: WHO, and Rome: FAO; 2006.

8. Tontisirin K, Nantel G, Bhattacharjee L. Food-based strategies to meet the challenges of micronutrient malnutrition in the developing world. Proc Nutr Soc 2002;61:243-50.

9. Mavengahama S, McLachlan $M$, de Clercq $W$. The role of wild vegetable species in household food security in maize based subsistence cropping systems. Food Sec 2013;5:227-33.

10. Chadha M, Oluoch M. Home-based vegetable gardens and other strategies to overcome micronutrient malnutrition in developing countries. Food Nutr Agr, 2003;32:17-23.

11. Flyman MV, Afolayan A. The suitability of wild vegetables for alleviating human dietary deficiencies. S Afr J Bot 2006;72:492-7.

12. Fairweather-Tait $S$, Lynch $S$, Hotz $C$, Hurrell $R$, Abrahamse $L$, Beebe $S$, et al. The usefulness of in vitro models to predict the bioavailability of iron and zinc: A consensus statement from the HarvestPlus expert consultation. Int J Vitam Nutr Res 2005;75:371-4.

13. Food Agriculture Organization of the United Nations (FAO).Cereals and other starchbased staples:are consumption

patterns 
changing?http://www.fao.org/docrep/MEETING/007/J1183E/J1183E00. HTM(accessed 07-10-2014); 2004.

14. Department of Health (DOH). Government Notice: Department of Health. Foodstuffs, Cosmetics and Disinfectants Act, No. R 2003. (Act No. 54 of 1972). Regulations relating to the fortification of certain foodstuffs. Pretoria: Department of Health.

15. Matenge STP, Van der Merwe D, De Beer H, Bosman MJC, Kruger A. Consumers' beliefs on indigenous and traditional foods and acceptance of products made with cow pea leaves. Afr J Agric Res 2012;2243-54.

16. Matenge STP, Van der Merwe D, Kruger A, De Beer H. Utilisation of indigenous plants foods in the urban and rural communities. IAJIKS 2011;10:17-37.

17. van der Hoeven, M. The effect of African leafy vegetables on the alleviation of micronutrient deficiencies in school children residing in the North West Province of South Africa (Thesis). North-West University. 2014. http://hdl.handle.net/10394/12204 (Accessed 18-02-2015).

18. Kaluza WZ, McGrath RM, Robberts C, Schroeder HH. Separation of phenolics of sorghum bicolor (L.) Moench grain. J Agr Food Chem 1980;28:1191-6.

19. Price ML, Van Scoyoc S, Butler LG. A critical evaluation of the vanillin reaction as an assay for tannin in sorghum grain. J Agr Food Chem 1978;26:1214-8.

20. Fruhbeck G, Alonso R, Marzo F, Santidrián S. A modified method for the indirect quantitative analysis of phytate in foodstuffs. Anal Biochem 1995;225:206-12.

21. Kruger J, Pineda-Vargas C, Minnis-Ndimba R, Taylor J. Visualisation of the distribution of minerals in red non-tannin finger millet using PIXE microanalysis. J Cereal Sci 2014;60:13.

22. Luten J, Crews H, Flynn A, Van Dael P, Kastenmayer P, Hurrell R et al. Interlaboratory trial on the determination of the in vitro iron dialysability from food. J Sci Food Agr 1996;2:415-24.

23. Kruger J, Taylor J, Du X, De Moura FF, Lönnerdal B, \&Oelofse A. Effect of phytate reduction of sorghum, through genetic modification, on iron and zinc availability as assessed by an in vitro dialysabilitybioaccessibility assay, Caco-2 cell uptake assay, and suckling rat pup absorption model. Food Chem 2013;141:1019-25.

24. Van Jaarsveld $P$, Faber M, Van Heerden I, Wenhold F, Jansen van Rensburg W, Van Averbeke W. Nutrient content of eight African leafy vegetables and their potential contribution to dietary reference intakes. J Food Comp Anal 2014;33:77-84. 
25. Hurrell RF. Influence of vegetable protein sources on trace element and mineral bioavailability. J Nutr 2003;133:2973S-77S.

26. Morris ER, Ellis R. Usefulness of the dietary phytic acid/zinc molar ratio as an index of zinc bioavailability to rats and humans. BiolTraceelem Res 1989;19:107-17.

27. Kumari M, Gupta S, Lakshmi AJ, Prakash J. Iron bioavailability in green leafy vegetables cooked in different utensils. Food Chem 2004;86:217-22.

29. Matuschek E, Towo E, Svanberg U. Oxidation of polyphenols in phytate-reduced hightannin cereals: effect on different phenolic groups and on in vitro accessible iron. J Agr Food Chem 2001;49:5630-38.

30. Greffeuille V, KayodéAPP, Icard-Vernière C, Gnimadi M, Rochette I, Mouquet-Rivier C. Changes in iron, zinc and chelating agents during traditional African processing of maize: Effect of iron contamination on bioaccessibility. Food Chem 2010;126:1800-7.

31. Kruger J, Taylor JRN, Oelofse A. Effects of reducing phytate content in sorghum through genetic modification and fermentation on in vitro iron availability in wholegrain porridges. Food Chem 2012;131:220-4.

32. Lönnerdal B. Dietary Factors Influencing Zinc Absorption. J Nutr 2000;130:1378S-83S.

33. FAO. Dimensions of need: People and populations at risk. http://www.fao.org/docrep/u8480e/u8480e05.htm(Accessed 11-9-2014); 1995.

34. Institute of medicine (IOM). Dietary Reference Intakes for Vitamin A, Vitamin K, Arsenic, Boron, Chromium, Copper, lodine, Iron, Manganese, Molybdenum, Nickel, Silicon, Vanadium, and Zinc. Washington DC: National Academy Press; 2001.

35. WHO. Iron deficiency anaemia; assessment, prevention and control. Geneva: WHO Press; 2008b.

36. FAO, WHO. Human Vitamin and Mineral Requirements, http://www.fao.org/docrep/004/Y2809E/Y2809E00.HTM (accessed 20-10-2014/); 2001. 